\title{
Prediction of Islamic Banking Bankruptcy in Indonesia: Comparative Study of Altman Z-Score and Springate Models
}

\author{
Shafitranata ${ }^{\mathrm{I}}$, Rizka Chairunnisa ${ }^{2}$, \\ Noman Arshed ${ }^{3}$ \\ STIE Al-Madani Bandar Lampung, Indonesia ${ }^{\mathrm{I}, 2}$, \\ University of Management and Technology, Pakistan ${ }^{3}$ \\ shafitranata@,almadani.ac.id ${ }^{1}, \underline{\text { rizka.chairunnisa@,almadani.ac.id }{ }^{2}}$, \\ noman.arshed@,umt.edu.pk
}

\begin{abstract}
Aim of this research is to calculate, measure, analyze, and evaluate predictions of potential bankruptcy of Islamic banking using the modified Altman Z-Score and Springate models and identify differences in the predicted results. This research uses descriptive quantitative analysis. Model analysis used is the Modified Altman Z-Score and Springate models. The research object used is I2 Islamic banks in Indonesia 2013-2019 and data collection includes literature study and observation.

Modified Altman Z-Score model predicts that I.19\% of Islamic banking is in gray area and $98.81 \%$ is in a non-bankrupt position. Meanwhile, the Springate model predicts $38.10 \%$ of Islamic banking is in a bankrupt position and 6I.90\% is in a non-bankrupt position. This research only analyzes and compares the prediction results of the potential bankruptcy of Islamic banking with the modified Altman Z-Score and Springate models. This research can be used as a policy brief for Islamic banking in Indonesia in facing the potential for bankruptcy so that companies improve their management and company performance.
\end{abstract}

Keywords: Islamic Banking, Bankruptcy, Altman Z-Score, Springate.

Received : December I6,2020 - Revised: December I6,2020 - Accepted: December 2I,2020

Occupuation : STIE Al-Madani Bandar Lampung ${ }^{1,2}$, University of Management and

Technology, Pakistan ${ }^{3}$

E-mail : shafitranata@,almadani.ac.id ${ }^{1^{*}}, \underline{\text { rizka.chairunnisa@,almadani.ac.id }{ }^{2}}$,

noman.arshed@umt.edu.pk ${ }^{3}$ 


\section{A. INTRODUCTION}

Banking is an important sector of the economy in Indonesia, the existence of banking indirectly helps economic growth in Indonesia. When the economic crisis occurred, the most influential sector was banking which affected the entire economy in Indonesia. Crisis in 1997 devastated the joints of the economy which later transformed into a prolonged economic crisis which had a negative effect on the performance of the Indonesian economy. This condition is reflected in the large number of banks that collapsed because they were deemed unable to maintain their going concern anymore, so they had to be liquidated.

Conventional banks were greatly affected by the crisis, forcing companies to carry out merger, acquisition, or even bankruptcy. This is different for Islamic banks that are able to continue to face a period of crisis with a different financial operational system by implementing a profit sharing system for deposits and loans so that it does not have an impact on the application of the interest system which causes financial difficulties for companies at that time. The company's financial difficulties can be actionable by maximizing the company's assets in obtaining sustainable profits.

The question arises whether Islamic banking is always immune to crisis that occurs. Based on Banking Crisis Index resilience test researched by (Rahman, 20I5), Islamic banks were indeed able to get through the crisis that occurred in 2008, but more conventional banks are establishing Islamic banks, making competition tighter in carrying out their operational activities. Concrete examples of Islamic bank mistakes that have an impact on company competition are Bank Muamalat's mistakes in implementing company's strategy, Bank Muamalat is considered too focused on corporate funding which has resulted in nonperforming financing increasing sharply (Saragih, 2019). Conditions that led to Islamic banking in Indonesia is not always invulnerable forever in encounter of crisis so need see furtherto predict bankruptcy Islamic banks.

Based on the audited financial reports of I2 Islamic Banks in Indonesia for 2013-2019, there are various categories of advantages of Islamic banking, ranging from Islamic banks that have increased every year, experienced fluctuations in profits, to decreased profits every year, as the following table: 
Table I: Comprehensive Profit of Islamic Banking in Indonesia, 2013-2019

\begin{tabular}{|c|c|c|c|c|c|c|c|c|}
\hline & & & & & & \multicolumn{3}{|c|}{ (in million rupiah) } \\
\hline No & BANK NAME & 2013 & 2014 & 2015 & 2016 & 2017 & 2018 & 2019 \\
\hline $\mathrm{I}$ & $\begin{array}{l}\text { PT Bank Syariah } \\
\text { Mandiri }\end{array}$ & 650,530 & 74,979 & 681,774 & 278,698 & $42 \mathrm{I}, 804$ & 724,924 & I,206,670 \\
\hline 2 & PT Bank & & & & & & & \\
\hline & $\begin{array}{l}\text { Muamalat } \\
\text { Indonesia }\end{array}$ & 165,290 & 712,463 & 672,169 & 100,153 & 249,389 & 41,348 & I5,5II \\
\hline 3 & PT Bank BNI & & & & & & & \\
\hline 4 & $\begin{array}{l}\text { Syariah } \\
\text { PT Bank BRI }\end{array}$ & I 17,462 & $\mathrm{I} 63,25 \mathrm{I}$ & 265,658 & 270,908 & 320,732 & 434,868 & 596,930 \\
\hline & Syariah & I29,564 & 6,577 & $\mathrm{I} 25,322$ & 170,202 & 92,827 & I07,II 4 & 67,870 \\
\hline 5 & $\begin{array}{l}\text { PT Bank Mega } \\
\text { Svariah Indonesia }\end{array}$ & & & & I & IUI & & 86.802 \\
\hline 6 & PT Bank BJB & נט, & טרנט,17 & & 110,214 & 141,210 & 001 & $00,00 \mathrm{~L}$ \\
\hline & Syariah & 28,315 & $2 \mathrm{I}, \mathrm{I} 22$ & $\mathrm{I} 2, \mathrm{II} 8$ & $4 \mathrm{I} 4, \mathrm{I} 83$ & 298,450 & 21,629 & 16,875 \\
\hline 7 & $\begin{array}{l}\text { PT Bank Panin } \\
\text { Dubai Syariah }\end{array}$ & $2 \mathrm{I}, 332$ & 70,938 & 73,895 & $27,30 \mathrm{I}$ & $(945,099)$ & 21,277 & 26,099 \\
\hline 8 & PT Bank Bukopin & & & & & & & \\
\hline 9 & $\begin{array}{l}\text { Syariah } \\
\text { PT Bank Victoria }\end{array}$ & 19,547 & 8,661 & 29,450 & 53,224 & 888 & 4,322 & $4,08 \mathrm{I}$ \\
\hline & Syariah & 6,362 & $(19,337)$ & $(23,716)$ & $(18,322)$ & 5,063 & $(8,143)$ & $\mathrm{I} 2,994$ \\
\hline 10 & PT Bank BCA & & & & & & & \\
\hline $\mathrm{J}$ & $\begin{array}{l}\text { Syariah } \\
\text { DT RTDN Swrin }\end{array}$ & $9, \mathrm{I} 4 \mathrm{I}$ & $\mathrm{I} 2,5 \mathrm{I} 6$ & 26,517 & 46,515 & 37,044 & 66,856 & $(235)$ \\
\hline & & I7I & 98,942 & $\mathrm{I} 74,5 \mathrm{I} 8$ & 422,473 & 655,904 & $\mathrm{I}, 003,747$ & $\mathrm{I}, 408,2 \mathrm{I} 8$ \\
\hline 12 & $\begin{array}{l}\text { PT Maybank } \\
\text { Syariah/Net } \\
\text { Syariah }\end{array}$ & 41,387 & 55,953 & $(294, \mathrm{II} 2)$ & $(\mathrm{I} 62,494)$ & $(8,46 \mathrm{I})$ & $(53,387)$ & 65,454 \\
\hline
\end{tabular}

Source: Annual Report on Islamic Banking 2013-2019 (Otoritas Jasa Keuangan, 2020)

Based on Table I, the decline in profits is a risk that companies need to watch out for each Islamic banking. To anticipate the various risks that may occur, it is necessary to take action as early as possible to measure the condition and health level of Islamic banking itself. Early warning system to predict a state of financial distress that leads to bankruptcy.

There are several analytical models that are often used to predict bankruptcy. Analysis models to predict bankruptcy include Altman (I968, I984), Springate (1978), Ohslon (I980), Whalen and Thomson (I988) models. However, from some of the analysis models, the most frequently used bankruptcy analyzes are the Altman Z-Score and the Springate models (Bowo \& Ayem, 2013). As the resulting research (Suparningsih \& Chaeriah, 20I9) states the Altman Z-Score model has a high deviation value compared to other models because it has three ranges in determining the cut off point, namely distress zone, gray zone and safe zone, while other models only has two ranges to determine the cut off point, namely distress zone and safe zone. The comparisons used to 
measure the potential for bankruptcy are Altman Z-Score and Springate models because the score formula used is a multivariate formula in measuring the financial health of the company.

The model developed by Altman uses 5 financial ratios to predict potential financial distress, while the Springate Model uses 4 financial ratios. The difference in financial ratios may cause differences in the predicted results. From the results of the predictions of the two models, it is not known which model is the most accurate in predicting financial difficulties in Islamic banking. In addition there may be differences in the predicted results, both models this bankruptcy have different levels of accuracy. According to research conducted by (Altman, 1968), the Altman Z-Score accuracy rate is around 95\% while Springate has an accuracy rate of $92.5 \%$, this is based on a test conducted by (Springate, 1978).

With a combination of these ratios, this analysis model will help the company's financial performance and can predict the potential bankruptcy that the company may experience. Assessment of potential bankruptcy is intended to assess the success of banks in the Indonesian economy, banking industry, to measure the soundness of banks in maintaining the intermediation function, as well as for early warning in facing changes in the banking business environment or changes in the country's economy.

Based on the description above, it is necessary to have an analysis to determine the condition of Islamic Banking which has a strategic function and an important aspect in improving the Indonesian economy. Researchers formulated several problems, namely How is the Modified Altman model and the Springate model in predicting Islamic banking bankruptcy in 2013-2019?; Are there any differences between Altman Z-Score and Springate models in predicting Islamic banking bankruptcy?

\section{B. THEORITICAL}

\section{Bankruptcy}

(Rudianto, 2013) defines bankruptcy as the incability company to disbursefinancial liabilities at maturity which causes bankruptcy or liquidity difficulties which may be the beginning of bankruptcy. According to (Rudianto, 2013), there are three types of failures in companies, namely:

a. Companies that face technically insolvent, if the company cannot fulfill its obligations which are due immediately but the value of the company's assets is higher than its debt. 
b. Companies that face legally insolvent, if the company's asset value is lower than the company's debt value.

c. A company that is facing bankruptcy, that is, if it cannot pay its debt and is declared bankrupt by the court.

\section{Analysis Bankruptcy Altman Z-Score Model}

Altman uses the function of discriminant analysis to predict company bankruptcy, themodel used is MDA (Multiple Discriminant Analysis) or better known as the Z-Score (Nur Hasanah, 2010). Z-Score analysis is designed to resolve the limitations of financial ratio analysis done separately.

MDA (Multiple Discriminant Analysis) is a form of multiple discriminant analysis in other words, the group that is owned as the dependent variable is no longer two, but three, four or more (Kartika, 2015). In building his model Altman uses financial ratios based on their popularity in literature and relevance research, the ratios used also have five criteria, namely ratios that can reflect liquidity, profitability, leverage, solvency, and activity ratios (Nur Hasanah, 2010).

\section{Altman Z-Score Original Model}

Initially Altman tested 22 financial ratios of 33 bankrupt manufacturing companies and 33 companies that did not go bankrupt from I960 to 1965 and in the end, it was found that five financial ratios were combined and considered the most influential to predict the potential bankruptcy of the companies (Altman, 1968). The first MDA formula invented by Altman is:

$$
Z=1,2 X_{1}+1,4 X_{2}+3,3 X_{3}+0,6 X_{4}+1,0 X_{5}
$$

$\mathrm{X}_{\mathrm{I}}=$ net working capital to total assets

$\mathrm{X}_{2}=$ retained earning to total assets

$\mathrm{X}_{3}=$ earning before interest and tax to total assets

$\mathrm{X}_{4}=$ market value of equity to book value of total debt

$\mathrm{X}_{5}=$ sales to total assets

$\mathrm{Z}=$ overall index

\section{Revised Altman Z-Score Model}

In 1984, Altman developing alternative discriminant model Z-Score before. In this research, Altman made adjustments so that this bankruptcy 
Prediction of Islamic Banking Bankruptcy in Indonesia: Comparative Study of Altman Z-Score and Springate Models

Shafitranata ${ }^{\mathrm{I}}$, Rizka Chairunnisa ${ }^{2}$, Noman Arshed ${ }^{3}$

prediction model can be used for companies that do not have equity market value or non-public companies (Kamal, 20I2). Changes or revisions were made to variable $\mathrm{X}_{4}$ where the previous variable was the market value of equity to book value of total debt to book value of equity to book value of total debt (Kamal, 2012).

The revised Z-Score model early are not encouraged at variable $\mathrm{X} 4$ ratio but also on value of coefficient for each variable. The $Z$ value for this model is also different from the $Z$ value in the previous model. The MDA formula developed by Altman is (Altman, I968):

$$
Z=0,717 X_{1}+0,847 X_{2}+3,107 X_{3}+0,420 X_{4}+0,998 X_{5}
$$

$\mathrm{X}_{\mathrm{I}}=$ net working capital to total assets

$\mathrm{X}_{2}=$ retained earning to total assets

$\mathrm{X}_{3}=$ earning before interest and tax to total assets

$\mathrm{X}_{4}=$ book value of equity to book value of total debt

$\mathrm{X}_{5}=$ sales to total assets

$\mathrm{Z}=$ overall index

\section{Modified Altman Z-Score Model}

Altman continues to develop his alternative discriminant analysis model, so that his bankruptcy prediction model can be used for all types of companies, such as manufacturing companies, non-manufacturing companies and bond issuing companies in developing countries (Ramadhani \& Lukviarman, 2009). In this modified Z-Score Altman eliminates the X 5 variable (sales/total assets) because this ratio is very varied in industries with different asset sizes (Ihsan \& Kartika, 20I6). Thus, the formula for the Z-Score equation which has been modified by Altman shows the discriminant function as following:

$$
Z=6,56 X_{1}+3,26 X_{2}+6,72 X_{3}+1,05 X_{4}
$$

\section{Springate Model}

The Springate Analysis Model was developed in 1978 at Simon Fraser University by Gordon LV Springate. Gordon follows the procedure of a model developed by Altman in the United States. Gordon uses discriminant analysis 
IKONOMIKA

Volum 5, No 2 (2020)

with several steps to identify 4 out of 19 financial ratios (Rajasekar et al., 20I4). The Springate model takes the following models:

$$
S=1,03 X_{1}+3,07 X_{2}+0,66 X_{3}+0,4 X_{4}
$$

From some of the explanations above, the research model can be described as follows:

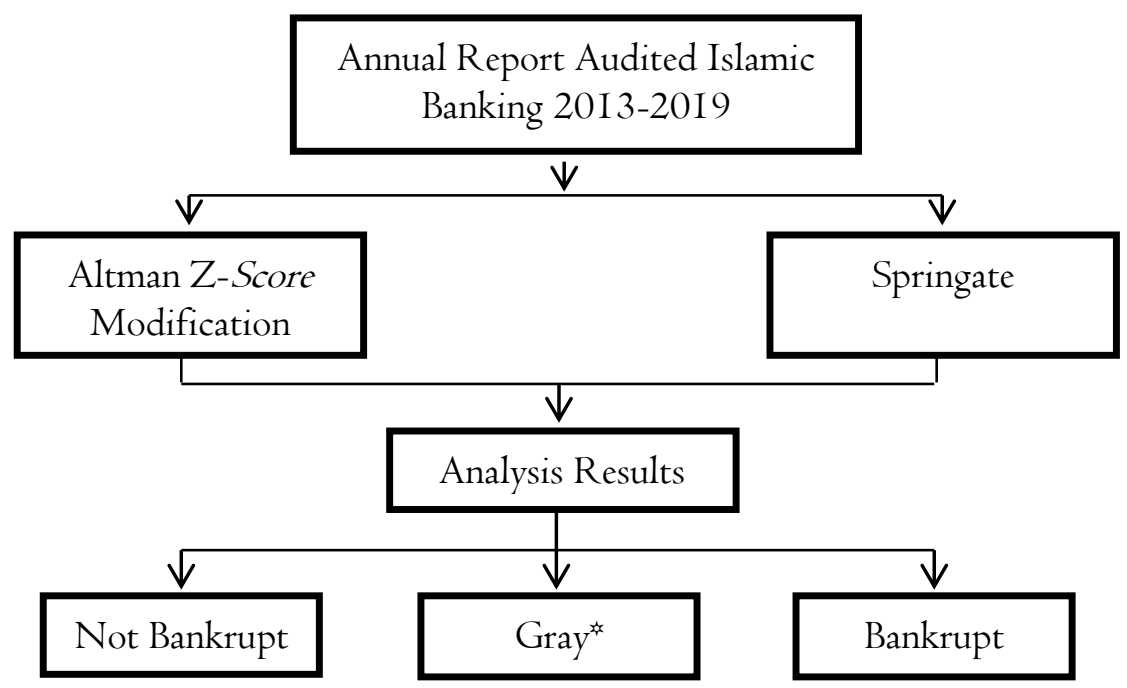

* Only used on the Altman Z-Score model

Figure I: Research Framework.

\section{METHODOLOGY}

The population of this research is all Islamic banking in Indonesia, including I2 Islamic banks. This research uses secondary data form annual report audited 2013-2019, data is taken from the websites of Bank Indonesia, OJK, and their respective companies. This research data collection technique using the method of desk research/literature study and observation.

This research is a quantitative descriptive study using three stages of analysis. The first stage measures the components of Altman and Springate ratios. Second, include these ratio components in Altman and Springate calculation formulas. The third stage is to classify the company based on Z-Score obtained, using the cut off point and comparing the results of Altman and Springate, as shown in the following figure: 
Prediction of Islamic Banking Bankruptcy in Indonesia: Comparative Study of Altman Z-Score and Springate Models

Shafitranata ${ }^{\mathrm{I}}$, Rizka Chairunnisa ${ }^{2}$, Noman Arshed ${ }^{3}$

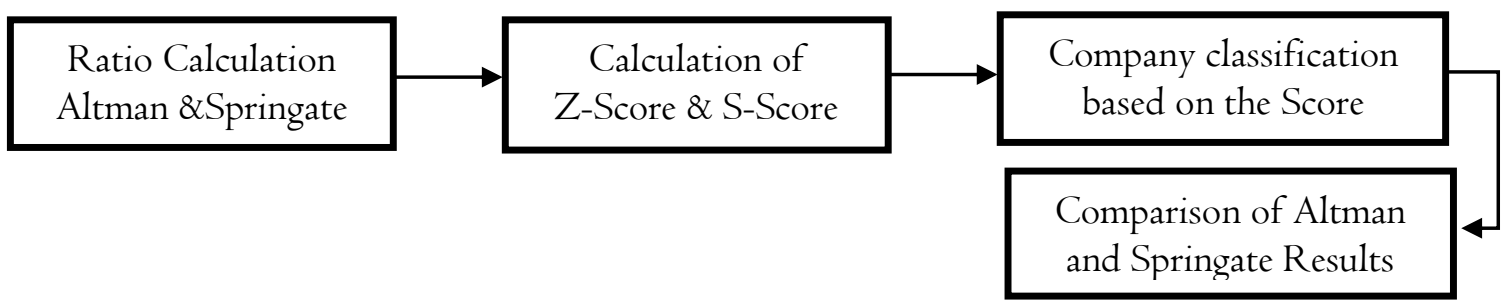

Figure 2. Data Analysis Phase

The data analysis of this research uses Multiple Discriminant Analysis (MDA) model calculation, namely Modified Altman Z-Score model to measure Islamic banking bankruptcy and Springate model as a comparison in predicting Islamic banking bankruptcy in Indonesia. As the resulting research (Suparningsih \& Chaeriah, 2019) states Altman Z-Score model has a high deviation value compared to other models because it has three ranges in determining the cut off point, namely distress zone, gray zone and safe zone, while other models only has two ranges to determine the cut off point, namely distress zone and safe zone. The comparisons used to measure the potential for bankruptcy are the Altman ZScore and the Springate models because the scoring formula used is a multivariate formula in measuring the company's financial health.

\section{Modified Altman Z-Score Model}

$$
Z=6,56 X_{1}+3,26 X_{2}+6,72 X_{3}+1,05 X_{4}
$$

$\mathrm{X}_{\mathrm{I}}=$ net working capital to total assets

$\mathrm{X}_{2}=$ retained earning to total assets

$\mathrm{X}_{3}=$ earning before interest and tax to total assets

$\mathrm{X}_{4}=$ book value of equity to book value of debt

$\mathrm{Z}=$ overall index

The calculation result will be classified as the following table:

Table 2. Classification of Z-Score.

\begin{tabular}{lc}
\hline \multicolumn{1}{c}{ Category } & Z-Score Value \\
\hline Bankrupt & $\mathrm{Z}<\mathrm{I}, 23$ \\
Grey Area & $\mathrm{I}, 23<\mathrm{Z}<2,90$ \\
Not Bankrupt & $\mathrm{Z}>2,90$ \\
\hline
\end{tabular}

Source : (Kartika, 20I5) 


\section{Springate Model}

The Springate model takes the following models:

$$
S=1,03 X_{1}+3,07 X_{2}+0,66 X_{3}+0,4 X_{4}
$$

$\mathrm{X}_{\mathrm{I}}=$ working capital to total assets

$\mathrm{X}_{2}=$ earnings before interest and taxes to total assets

$\mathrm{X}_{3}=$ earnings before taxes to current liabilities

$\mathrm{X}_{4}=$ sales to total assets

This Springate model has a standard where companies that have a score of $\mathrm{S}>0.862$ are classified as healthy or not bankrupt companies, while companies that have a score of $S<0.862$ are classified as potentially bankrupt companies (Peter \& Yoseph, 20I I).

\section{RESULTS AND DISCUSSION}

\section{Modified Altman Z-Score Method}

Financial data is obtained from audited financial statements of Islamic Banking 2013-2019 to form a variable Z-Score value consisting of net working capital, total asset, retained earning, earning before interest and taxes, book value of equity, and book value of total debt. Then the results of the formation of the variable Z-Score value are combined into the modified Altman Z-Score equation model by multiplying the resulting data by the constant or standard value of each variable. The results of modified Z-Score calculation is shown on the following table:

Table 3. Modification Z-Score Calculation Results.

\begin{tabular}{ccccccccc}
\hline \multirow{2}{*}{ No } & \multirow{7}{*}{ Company } & \multicolumn{7}{c}{ Z-Score Prediction } \\
\cline { 3 - 8 } & & $\mathbf{2 0 I 3}$ & $\mathbf{2 0 I 4}$ & $\mathbf{2 0 1 5}$ & $\mathbf{2 0 1 6}$ & $\mathbf{2 0 I 7}$ & $\mathbf{2 0 1 8}$ & 2019 \\
\hline I & PT Bank Syariah & 5.533 & 5.729 & 5.639 & $5.69 \mathrm{I}$ & 5.615 & 5.696 & 5.635 \\
& Mandiri & Not & Not & Not & Not & Not & Not & Not \\
& & Bankrupt & Bankrupt & Bankrupt & Bankrupt & Bankrupt & Bankrupt & Bankrupt \\
2 & PT Bank Muamalat & 5.182 & 5.213 & 4.997 & 4.892 & 4.636 & 4.928 & 4.986 \\
& Indonesia & Not & Not & Not & Not & Not & Not & Not \\
& & Bankrupt & Bankrupt & Bankrupt & Bankrupt & Bankrupt & Bankrupt & Bankrupt \\
3 & PT Bank BNI & 4.888 & 5.599 & 5.726 & 5.593 & 5.424 & 5.133 & 4.980 \\
& Syariah & Not & Not & Not & Not & Not & Not & Not \\
& & Bankrupt & Bankrupt & Bankrupt & Bankrupt & Bankrupt & Bankrupt & Bankrupt
\end{tabular}




\begin{tabular}{|c|c|c|c|c|c|c|c|c|}
\hline \multirow[t]{3}{*}{4} & PT Bank BRI & $4.87 \mathrm{I}$ & 4.676 & 4.782 & 4.490 & 4.554 & 4.340 & 4.645 \\
\hline & Syariah & Not & Not & Not & Not & Not & Not & Not \\
\hline & & Bankrupt & Bankrupt & Bankrupt & Bankrupt & Bankrupt & Bankrupt & Bankrupt \\
\hline \multirow[t]{3}{*}{5} & PT Bank Mega & 5.070 & $5.22 \mathrm{I}$ & 5.302 & $6.127^{1}$ & $5.348^{1}$ & $5.820^{1}$ & 5.850 \\
\hline & Syariah Indonesia & Not & Not & Not & Not & Not & Not & Not \\
\hline & & Bankrupt & Bankrupt & Bankrupt & Bankrupt & Bankrupt & Bankrupt & Bankrupt \\
\hline \multirow[t]{3}{*}{6} & PT Bank BJB Syariah & 5.516 & 5.993 & 6.118 & $5.005^{1}$ & 5.034 & $5.157^{1}$ & 5.091 \\
\hline & & Not & Not & Not & Not & Not & Not & Not \\
\hline & & Bankrupt & Bankrupt & Bankrupt & Bankrupt & Bankrupt & Bankrupt & Bankrupt \\
\hline \multirow[t]{3}{*}{7} & PT Bank Panin & 5.973 & $5.73 \mathrm{I}$ & $5.89 \mathrm{I}$ & 5.739 & 4.870 & 5.212 & 5.587 \\
\hline & Dubai Syariah & Not & Not & Not & Not & Not & Not & Not \\
\hline & & Bankrupt & Bankrupt & Bankrupt & Bankrupt & Bankrupt & Bankrupt & Bankrupt \\
\hline \multirow[t]{3}{*}{8} & PT Bank Bukopin & 4.643 & 5.164 & 5.398 & 5.102 & 6.190 & 6.152 & 6.256 \\
\hline & Syariah & Not & Not & Not & Not & Not & Not & Not \\
\hline & & Bankrupt & Bankrupt & Bankrupt & Bankrupt & Bankrupt & Bankrupt & Bankrupt \\
\hline \multirow[t]{3}{*}{9} & PT Bank Victoria & 6.103 & 6.033 & 5.760 & 5.233 & 5.692 & 5.260 & 6.038 \\
\hline & Syariah & Not & Not & Not & Not & Not & Not & Not \\
\hline & & Bankrupt & Bankrupt & Bankrupt & Bankrupt & Bankrupt & Bankrupt & Bankrupt \\
\hline \multirow[t]{3}{*}{ I0 } & PT Bank BCA & 5.247 & 5.737 & 6.038 & $6.12 \mathrm{I}$ & 5.842 & 5.892 & 5.365 \\
\hline & Syariah & Not & Not & Not & Not & Not & Not & Not \\
\hline & & Bankrupt & Bankrupt & Bankrupt & Bankrupt & Bankrupt & Bankrupt & Bankrupt \\
\hline \multirow[t]{3}{*}{ I I } & PT BTPN Syariah & 3.375 & 5.306 & 5.656 & 5.847 & 6.382 & 6.693 & 7.029 \\
\hline & & Not & Not & Not & Not & Not & Not & Not \\
\hline & & Bankrupt & Bankrupt & Bankrupt & Bankrupt & Bankrupt & Bankrupt & Bankrupt \\
\hline \multirow[t]{3}{*}{$\mathrm{I} 2$} & PT Maybank & 5.364 & 5.644 & 3.465 & 3.232 & $4.20 \mathrm{I}$ & 2.726 & 4.770 \\
\hline & Syariah/Net Syariah & Not & Not & Not & Not & Not & Grey & Not \\
\hline & & Bankrupt & Bankrupt & Bankrupt & Bankrupt & Bankrupt & Area & Bankrupt \\
\hline
\end{tabular}

Source: Data processed in 2020

The results of Z-Score calculation shows that overall Islamic Banking in Indonesia in 2013-2019 shows the condition of the company that is not bankrupt/healthy. Are in line with research (Kartika, 2015) which states the Z- Score value of Islamic Banking above 2.90, which is the non-bankrupt criterion in the modified Z-Score model. However, there is I Islamic bank classified in the gray area/prone to bankruptcy, namely PT Maybank Syariah in 2018 with a Z-Score of 2,726 . The company's financial condition is in line with the results of the bankruptcy prediction which shows unfavorable conditions, the retained earnings balance which tends to decline from the previous year, negative profits, decreased sales, and even did not sell shares in that year, causing the calculation of the ratio to fluctuate.

In 2019 the results of the Z-Score calculation of PT Maybank Syariah shows very positive results with an increase of $57 \%$ with a Z-Score of 4,770 or 
more than the classification of companies that are not bankrupt above 2.90. This is due to the purchase of $100 \%$ shares of PT Maybank Syariah by PT NTI Global Indonesia (NTI Global) and PT Berkah Anugerah Abadi (Berkah Anugerah) in 2019. So there was a change in the name previously PT Maybank Syariah became PT Bank Net Syariah (Tahir Saleh, 2020). Acquisition of PT Maybank Syariah is able to change the company's performance so that it can optimize the company's assets in generating optimal profits.

The process of calculating the Z-Score value using the modified Altman Z-Score model above, it can be known that all Sharia Banks in 2013-2019 are in the non-bankrupt category, except for PT Maybank Syariah in 2018 which has a Z-Score below 2.90, which is 2,726. The average Z-Score for all Islamic banks in 2013-2019 is shown in the graph below:

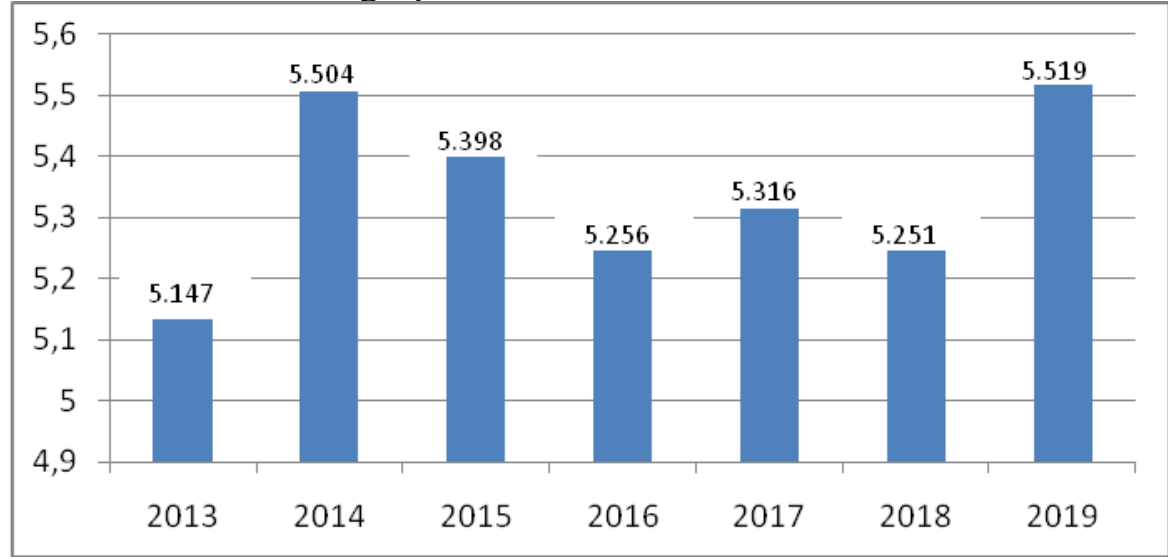

\section{Figure 3. Average Value Altman Z-Score Islamic Banking Year 2013-20I9 S-Score Method}

Financial data were obtained from audited financial reports for Islamic Banking 2013-2019 to form a variable S-Score value consisting of working capital, total assets, earnings before interest and taxes, earnings before taxes, current liabilities, and sales. Then the results of the formation of the S-Score value variable are combined into the Springate S-Score equation model by multiplying the resulting data by the constant or standard value of each variable. The results of the S-Score calculation is shown on the following table:

Table 4. S-Score Calculation Results

\begin{tabular}{|c|c|c|c|c|c|c|c|c|}
\hline \multirow{2}{*}{ No } & \multirow{2}{*}{ Company } & \multicolumn{7}{|c|}{ S-Score Prediction } \\
\hline & & 2013 & 2014 & 2015 & 2016 & 2017 & 2018 & 2019 \\
\hline I & Bank Syariah & 0.939 & 0.899 & 0.903 & 0.919 & 0.910 & $0.94 \mathrm{I}$ & 0.967 \\
\hline
\end{tabular}




\begin{tabular}{|c|c|c|c|c|c|c|c|c|}
\hline \multirow{4}{*}{2} & Mandiri & Not & Not & Not & Not & Not & Not & Not \\
\hline & & ankrupt & Bankrupt & Bankrupt & krupt & $\mathrm{pt}$ & Bankrupt & Bankrupt \\
\hline & PT Bank & 848 & 0.83 & 0.80 & 0.787 & 0.73 & 0.782 & 0.739 \\
\hline & Muam & inkru & Bankrupt & Bankrupt & ankrupt & ankrupt & Bankrupt & Bankrupt \\
\hline & Indonesia & & & & & & & \\
\hline \multirow{2}{*}{3} & PT Bank B & 0.83 & 0.96 & & 0.9 & & 0.8 & \\
\hline & Syari & & $\begin{array}{l}\text { Not } \\
\text { Bankrupt }\end{array}$ & $\begin{array}{c}\text { Not } \\
\text { Bankrupt }\end{array}$ & $\begin{array}{l}\text { Not } \\
\text { Bankrupt }\end{array}$ & $\begin{array}{c}\text { Not } \\
\text { Bankrupt }\end{array}$ & $\begin{array}{c}\text { Not } \\
\text { Bankrupt }\end{array}$ & \\
\hline \multirow[t]{2}{*}{4} & PT Bank BRI & 0.82 & 0.7 & 0.7 & 0.7 & 0.7 & 0.714 & 0.758 \\
\hline & Syari & ank & Bar & $\mathrm{Ba}$ & & t & $\mathrm{Bar}$ & Banl \\
\hline \multirow[t]{3}{*}{5} & PT B & 0.96 & 0.8 & 0.8 & I.I & 0.8 & $0.92-2 x-2$ & 0.936 \\
\hline & Syariah & No & Ban & $N$ & $\mathrm{~N}$ & $\mathrm{~N}$ & $\mathrm{~N}$ & $\mathrm{~N}$ \\
\hline & & Bank & & & & & & Bar \\
\hline \multirow[t]{3}{*}{6} & PT Bank BJB & & $0.97 \mathrm{I}$ & & & & & \\
\hline & Syariah & $N$ & $\mathrm{~N}$ & & Bankrupt & Bankrupt & N & Bankrupt \\
\hline & & Ban & & & & & & \\
\hline \multirow[t]{3}{*}{7} & PT l & & & & 0.9 & -0. & & 0.916 \\
\hline & Duk & & $\mathrm{N}$ & & $\mathrm{N}$ & bt & N & $\mathrm{N}$ \\
\hline & & Ва & & & $\mathrm{Ba}$ & & & $\mathrm{Ba}$ \\
\hline \multirow[t]{3}{*}{8} & PT l & & & & & 0.97 & & \\
\hline & Syari & Bank & Bankrupt & $\mathrm{N}$ & Bankrupt & Not & $\mathrm{N}$ & Not \\
\hline & & & & & & Bankrupt & Ban & Bankrupt \\
\hline \multirow[t]{3}{*}{9} & k Victoria & 0.972 & 0.6 & & 0.72 & 0.932 & & 0.877 \\
\hline & Syariah & No & Bankrupt & Bankrupt & Bankrupt & Not & Bankrupt & Not \\
\hline & & & & & & Bankrupt & & Bankrupt \\
\hline \multirow[t]{3}{*}{10} & PT Bank BCA & 0.880 & 0.946 & 1.00 & 1.04 & 0.977 & 0.980 & 0.884 \\
\hline & Syariah & $\mathrm{T}$ & Not & NI & Not & No & $N$ & Not \\
\hline & & Banl & Bankrupt & cupt & ankrupt & Bankrupt & Bankrupt & Bankrupt \\
\hline \multirow[t]{3}{*}{ I I } & PT BTPN & & I.06 & . & 1.380 & I.582 & I.676 & $\mathrm{I} .82 \mathrm{I}$ \\
\hline & Syariah & Bankrupt & & & $N_{2}$ & $\mathrm{~N}$ & N & Not \\
\hline & & & Bankrupt & Bankrupt & Bankrupt & Bankrupt & Bankrupt & Bankrupt \\
\hline \multirow[t]{3}{*}{12} & PT Maybank & 0.95 & I.022 & & $0 . \mathrm{I}$ & I.0I4 & & 1.582 \\
\hline & Syariah/Net & No & No & Bankrupt & Bankrupt & No & Bankrupt & No \\
\hline & Syariah & DaासL & Bankrupt & & & Bankrupt & & Bankrup \\
\hline
\end{tabular}

Source: Data processed in 2020

Based on the S-Score calculation, it shows different results from the Altman Z-Score calculation. The results of the calculation of Springate show that the S-Score of the company is less than 0.862 and consistently every year, namely PT Bank Muamalat Indonesia and PT Bank BRI Syariah, this is supported by research (Imam Asyrofi, 2019) which states that the company is classified as a bankrupt company. This can also be seen from the financial performance of companies that have poor financial conditions, including the increasing amount of current debt, not accompanied by maximum company 
profits, so that company profits can only be used for operational activities and paying current debts.

Furthermore, there are companies that have fluctuations in the S-Score calculation, including PT Bank BNI Syariah in 2013 and 2019 was classified as a bankrupt company, PT Bank Mega Syariah Indonesia in 2014 was classified as a bankrupt company but in the following year it showed good condition, PT Bank BJB Syariah in 2016, 2017, and 2019, PT Panin Dubai Syariah Bank in 2017, PT Bukopin Syariah in 2013, 20I4, and 2016, PT Victoria Syariah in 2014, 20I5, 2016 and 20I8, PT Bank BTPN Syariah in 2013 this was due to the fact that the company was still a Sharia Business Unit of Bank Bukopin and in 2014 it had been spin-off so as to improve company performance, even the S-Score value of Bank BTPN Syariah had a positive trend and was the highest among other Islamic banks. And the last is PT Maybank Syariah in 2015, 2016 and 2018 before changing its name to PT Bank Net Syariah in 2019.

Meanwhile, companies that have no potential for bankruptcy are PT Bank Syariah Mandiri and PT Bank BCA Syariah. This can be observed from the company's financial performance which shows good and consistent conditions. The company's working capital continues to increase every year, the ability to manage company assets to generate company profits increases every year, and is able to manage the company's current debt properly.

Based on the results of the S-Score calculation process using the Springate model above, it can be seen that there are variations in the S-Score results on Islamic Banking 2013-2019, there are 2 banks classified as not bankrupt, and 2 banks classified as bankrupt, while 8 banks have the classification. Different conditions with bankruptcy and not bankruptcy in different years. The average SScore for all Sharia Banks in 2013-20I9 is shown in the graph below:

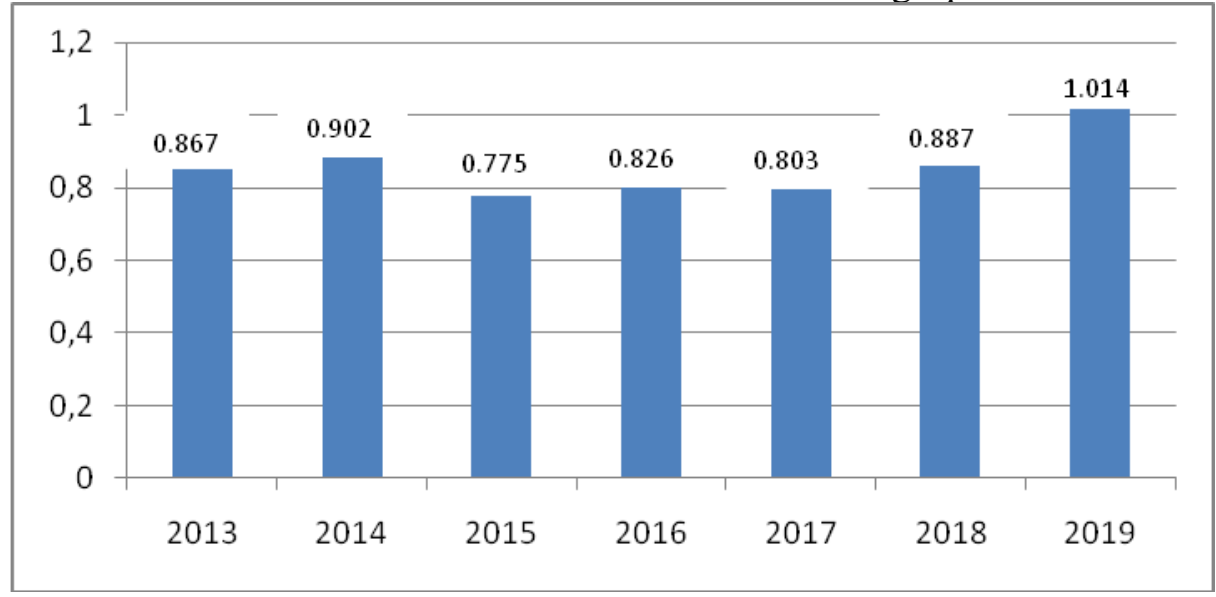

Figure 4. Average Value Springate S- Score Islamic Banking Year 20I3-20I9 
Prediction of Islamic Banking Bankruptcy in Indonesia: Comparative Study of Altman Z-Score and Springate Models

Shafitranata ${ }^{\mathrm{I}}$, Rizka Chairunnisa ${ }^{2}$, Noman Arshed ${ }^{3}$

Table 5. Percentage Comparison of Altman Z-Score Modification and Springate on Islamic Banking in Indonesia 2013-2019

\begin{tabular}{ccc}
\hline \multirow{2}{*}{ Category } & \multicolumn{2}{c}{ Percentage of Model Comparisons } \\
& Altman Z-Score & Springate S-Score \\
\hline Not Bankrupt & $98.81 \%$ & $61.90 \%$ \\
Grey Area & $1.19 \%$ & \\
Bankrupt & - & $38.10 \%$ \\
\hline
\end{tabular}

Source: Data processed in 2020

Based on Table 5 above, the Altman model predicts I.19\% of Islamic banking is in the gray area or prone to bankruptcy and $98.81 \%$ is in a position not bankrupt. Meanwhile, the Springate model predicts $38.10 \%$ of Islamic banking is in a bankrupt position and 6I.90\% is in a non-bankrupt position. When viewed from the company's financial condition, the Altman model predicts I.19\% or I company in a condition that is prone to bankruptcy shows the same results between Altman's predictions and the company's condition. Meanwhile, the Springate model has varying results with the condition of the company being bankrupt and not bankrupt.

The most appropriate comparison of prediction from Altman and Springate models is Altman Z-Score based on prediction results and the company's financial condition. This is in contrast with research (Hariyani \& Sujianto, 2017) which states that Islamic Banking is not suitable to use Altman Z-Score original or Altman Z-Score revision, because the model created to predict the bankruptcy of companies manufacture either already go public and that not yet. However, the research is in line with research (Suparningsih \& Chaeriah, 2019) and (Arum \& Handayani, 2018) which state that Altman Z-Score Modification is quite higher than use other bankruptcy models because the Altman Z-Score model has three ranges to determine the cut point. Off Point (bankrupt, gray area, not bankrupt) so that the company can immediately improve management and company performance.

\section{E. CONCLUSION}

Based on the identification of the predetermined problems and the research objectives to be achieved so that the author can obtain research results regarding the prediction of Islamic banking bankruptcy in Indonesia using the Altman ZScore and Springate models in 2013-2019 and supported by theories and articles that have been read and studied, it is obtained Conclusions are (I) By using 
Altman Z-Score to predict Islamic banking bankruptcy in 2013-2019, there are companies that are predicted to be prone to bankruptcy or experience financial distress, namely PT Maybank Syariah in 2018 with a Z- Score of 2,726 is at $I .23<Z<2.90$ or in the gray area category. (2) By using the Springate model in predicting the bankruptcy of Islamic Banking in 2013-2019, there are companies that are predicted to consistently go bankrupt, namely PT Bank Muamalat Indonesia and PT Bank BRI Syariah with company S-Score value of less than 0.862. There are companies that are predicted to go bankrupt and have fluctuations in the S-Score each year, namely PT Bank BNI Syariah, PT Bank Mega Syariah Indonesia, PT Bank BJB Syariah, PT Panin Dubai Syariah Bank, PT Bukopin Syariah, PT Victoria Syariah, PT Bank BTPN Syariah, PT Maybank Syariah. Meanwhile, companies that have no potential for bankruptcy are PT Bank Syariah Mandiri and PT Bank BCA Syariah. (3) Based on the comparison of the calculation of the Altman and Springate models and related to the company's financial condition in 2013-2019, the Modified Altman Z-Score model is quite high in predicting company bankruptcy compared to the Springate model. The Altman Z-Score model has three cut-off point classifications, namely bankruptcy, gray zone, and not bankruptcy so that this classification can be a warning to companies in improving company performance.

\section{Limitation and Further Research}

This research only analyzes, evaluates, and compares the prediction results of the potential bankruptcy of Islamic banking in 2013-2019 using modified Altman Z-Score and Springate models. Next researcher able to use the company object which is quite broad and with other bankruptcy prediction models. As well as not only assessing the company's financial condition, but also considering the qualitative aspects of the company such as economic, social, technological factors, and changes in the business environment.

\section{Research Contribution}

This research can serve as a policy brief for Islamic banking in Indonesia and evaluate the company's financial performance, including use of company assets to generate profits and efficiency of company operations. 


\section{REFERENCES}

Altman, E. I. (1968). Financial Ratios: Discriminan Analysis and The Prediction of Coporate Bankruptcy. The Journal of Finance, 23(4), 589. https://doi.org/I0.II I I/j.I540-626I.1968.tb00843.x

Arum, D. P., \& Handayani, S. R. (2018). Analisis Perbandingan Metode Altman (Z-Score), Springate (S- Score), dan Zmijewski (X-Score) dalam Memprediksi Kebangkrutan Perusahaan (Studi pada Perusahaan Tekstil dan Garmen yang Terdaftar di Bursa Efek Indonesia Periode 2012-2016). Jurnal Administrasi Bisnis, 60(I), I09-II8.

Bowo, U. N. A., \& Ayem, S. (20I3). Analisis Perbandingan Model Altman Modifikasi Dan Springate Untuk Memprediksi Kebangkrutan Pada Perusahaan Perbankan Yang Terdaftar Di Bursa Efek Indonesia Sebelum Dan Sesudah Adanya Lembaga Penjamin Simpanan. Jurnal Akuntansi, I(2), II-2I. https://doi.org/I0.24964/ja.vIi2.I2

Hariyani, D. S., \& Sujianto, A. (2017). Analisis Perbandingan Model Altman, Model Springate, Dan Model Zmijewski Dalam Memprediksi Kebangkrutan Bank Syariah Di Indonesia. Inventory: Jurnal Akuntansi, I(I), I3-23. https:// doi.org/I0.25273/inventory.vIiI.2289

Ihsan, D. N., \& Kartika, S. P. (2016). Potensi Kebangkrutan Pada Sektor Perbankan Syariah Untuk Menghadapi Perubahan Lingkungan Bisnis. Etikonomi, I4(2), I I3-I46. https:// doi.org/I0.I5408/etk.vI4i2.2268

Imam Asyrofi. (2019). Analisis Risiko Kebangkrutan Bank Syariah dengan Metode Altman Z-Score, Springate, dan Zmijewski X-Score (Studi Pada Bank Umum Syariah Periode 2014-2018). Unpublised Thesis, 53(9), I689-1699. https://doi.org/I0.1017/CBO978II07415324.004

Kamal, S. I. M. (2012). Analisis Prediksi Kebangkrutan pada Perusahaan Perbankan Go Public di Bursa Efek Indonesia (Dengan Menggunakan Model Altman Z-Score). Unpublised Masters Thesis, October 2012.

Kartika, S. P. (2015). Potensi Kebangkrutan pada Sektor Perbankan Syariah untuk Menghadapi Perubahan Lingkungan Bisnis dengan Menggunakan Model Altman Z-Score Modifikasi (Studi Bank Umum Syariah di Indonesia Periode 20I0-20I4). NASPA Journal, 42(4), I. https://doi.org/I0.I017/CBO978I I07415324.004

Nur Hasanah. (20I0). Analisis rasio keuangan model altman dan model springate sebagai. Unpublised Thesis.

Otoritas Jasa Keuangan. (2020). Laporan Publikasi Bank Umum Syariah. 
IKONOMIKA

Volum 5, No 2 (2020)

Webiste Otoritas Jasa Keuangan.

https://www.ojk.go.id/id/kanal/perbankan/data-dan-statistik/laporan-

keuangan-perbankan/default.aspx\#

Peter, \& Yoseph. (20II). Analisis Kebangkrutan Dengan Metode Z-Score

Altman, Springate dan Zmijewski Pada PT.Indofood Sukses Makmur TBK

Periode 2005-2009. Akurat Jurnal Ilmiah Akuntansi, 2(6), I-23.

Rahman, M. E. (20I5). Uji Ketahanan Krisis Terhadap Perbankan Syariah Di

Indonesia Dengan Ukuran Ibc (Indeks Banking Crisis ) Tahun Periode 2006-2012. Jebis, I(I), 79-88.

Rajasekar, T., Ashraf, S., \& Deo, M. (2014). An Empirical Enquiry on the

Financial Distress of Navratna Companies in India Pondicherry Central

University Pondicherry Central University. Journal of Accounting and

Finance, I4(1987), IO0-IIO.

Ramadhani, A. S., \& Lukviarman, N. (2009). Perbandingan Analisis Prediksi

Kebangkrutan Menggunakan Model Altman Pertama, Altman Revisi, dan

Altman Modifikasi dengan Ukuran dan Umur Perusahaan sebagai Variabel

Penjelas (Studi Pada Perusahaan Manufaktur yang Terdaftar di Bursa Efek Indonesia). Jurnal Siasat Bisnis, I3(I), I5-28. https://doi.org/I0.20885/jsb.volI3.iss I.art2

Rudianto. (2013). Akuntansi Manajemen Informasi untuk Pengambilan Keputusan Strategis. Erlangga.

Saragih, H. P. (2019, November). Terungkap! Ini Penyebab Masalah Kronis di

Bank Muamalat. CNBC Indonesia.

https://www.cnbcindonesia.com/market/2019I I I5093424-I7-

I I5443/terungkap-ini-penyebab-masalah-kronis-di-bank-muamalat

Springate, G. L. V. (1978). Predicting The Possibility of Failure in a Canadian

Firm. Unpublised Masters Thesis.

Suparningsih, B., \& Chaeriah, E. S. (2019). Perbandingan Prediksi Kebangkrutan

Menggunakan Model Altman Modifikasi, Springate, Zmijewski dan Grover

PT. Ratu Prabu Energi, Tbk. Jurnal Manajemen Bisnis Krisnadwipayana, $7(3)$

Tahir Saleh. (2020). Ganti Nama Jadi Bank Net, Maybank Syariah Resmi Dicaplok. CNBC Indonesia. https://www.cnbcindonesia.com/market/20200209I24846-I7-

I3643 I/ganti-nama-jadi-bank-net-maybank-syariah-resmi-dicaplok

https://ejournal.radenintan.ac.id/index.php/ikonomika 
Prediction of Islamic Banking Bankruptcy in Indonesia: Comparative Study of Altman Z-Score and Springate Models

Shafitranata ${ }^{\mathrm{I}}$, Rizka Chairunnisa ${ }^{2}$, Noman Arshed ${ }^{3}$ 